Corresponding Author: Analizza Ina Lea; email:

lizzalea2908@gmail.com

Published: 7 February 2022

Publishing services provided by Knowledge E

(c) Analizza Ina Lea et al. This article is distributed under the terms of the Attribution License, which permits unrestricted use and redistribution provided that the original author and source are credited.

Selection and Peer-review under the responsibility of the IVCN Conference Committee.

\section{Emergency Nurses' Knowledge and Practices Regarding Triage}

\author{
Analizza Ina Lea*, Erna Febriyanti, and Nurhayaty Odja \\ Citra Bangsa University, Kupang, East Nusa Tenggara
}

ORCID

Analizza Ina Lea: https://orcid.org/0000-0001-7963-3975

\begin{abstract}
Triage is the most important step in the emergency room. Triage is useful for ensuring that every patient gets rapid, precise, responsive and accurate treatment according to their condition based on ABCDE (airway, breathing, circulation, disability, environment) priorities. For this reason, it is necessary for nurses to be competent in the knowledge and skills related to triage. This study aimed to determine the association between knowledge and the implementation of triage by nurses at the Siloam Hospital in Kupang. This quantitative research used a correlative research design with a cross-sectional approach. 25 emergency nurses were recruited through saturation sampling. The instruments used in this study were a questionnaire, an observation sheet, and a checklist guided by the Service Operational Standards (SOP) for Triage Implementation. Data were analyzed using the Chi-square test. There was a significant relationship found between knowledge and the implementation of triage $(p=0.003)$. Therefore, it is important to optimize the nursing workforce, make arrangements related to their workload, enhance their motivation, and continue to improve their knowledge, skills and obedience in the emergency room through training programs and supervision.
\end{abstract}

Keywords: knowledge, implementation, triage

\section{Introduction}

Triage is the most important step in the emergency room. Triage is useful to ensure that every patient gets fast, precise, responsive and accurate treatment according to their condition based on ABCDE (Airway, Breathing, Circulation, Disability, Environment) priorities [1]. Emergency patients by triage nurses are carried out by general inspection, history taking, and measuring vital signs and then labeled according to the accompanying emergency conditions, namely red for emergent patients, yellow for urgent patients, green for non-urgent patients and black for deceased patients [1].

A study showed that, the factors most related to the implementation of triage are performance, patient factors and workforce factors [2]. The accuracy of nurses in carrying out triage is also influenced by other factors, such as nurses' knowledge about triage, work motivation and workload [3]. The ability of nurses to perform triage greatly affects the success rate of help when the patient experiences an emergency condition [4]. Knowledge is one of the most important factors in the accuracy of triage implementation 
[5]. Several emergency rooms in East Java showed that nurses' cognitive abilities regarding triage were still lacking, especially in determining procedures and patient disease management [2]. In addition, nurses' psychomotor abilities regarding triage are also still in the moderate category [2]. Knowledge is the result of knowing, occurs after people sense a certain object through the human senses, and most of it is obtained through the eyes and ears [6]. Knowledge in triage affects making the right decision to determine whether the patient needs immediate help or not while paying attention to possible complications that arise after triage is carried out [7].

Based on research [8], in the ER Wates Hospital on the Relationship between Knowledge Level and Nurses' Skills in Implementing Triage, it showed a significant relationship between knowledge level and skills in triage implementation. Likewise, research conducted by [9] which also explains that there is a correlation between the level of knowledge of nurses about response time in determining triage. The better the level of knowledge, the more skilled a nurse will be in implementing triage [2]. Conversely, a low level of knowledge can affect the inaccuracy of triage assessments so that they have the risk of decreasing patient safety rates and the quality of health services [10]. All hospitals in Kupang have triage rooms, including Siloam Hospital. Siloam Hospital has even developed more rooms with the intention that triage actions can be carried out maximally. However, until now, there are still nurses in the emergency room of Siloam Kupang Hospital who have not utilize the triage place maximally. Whereas the ER Siloam Kupang Hospital has provided Service Operational Standards (SOP) and facilities to support triage implementation.

The results of an interview with head office of ER Siloam Kupang Hospital in May 2020 said the triage rooms and beds are provided in ER Siloam Kupang Hospital. When making observations at the ER Siloam Hospital Kupang on May 22, 2020, it was found that some nurses who were on duty had not used the triage table that had been provided. All new patients are directed and placed in the yellow triage zone immediately. After that, the patient will be assessed and classified according to their condition. When conducting interviews with 3 ER nurses, they said that some ER nurses who had attended special emergency training only did visual triage by looking at their awareness, breathing and skin color (cyanosis or not cyanosis). Meanwhile, emergency room nurses who have not attended any emergency training more often just assess the patients from their general condition and are immediately directed to the yellow zone bed without doing triage at the triage table first. Of the three ER nurses at Siloam Kupang Hospital, only one of them who knew the SOP for the complete triage implementation procedure, starting from the triage system used, color category, response time and 
technical instructions for triage implementation, while the other 2 nurses only knew triage was the process of selecting patients based on their emergency condition.

This study was aimed to examine the relationship between nurses' knowledge and implementation of triage in the emergency room. The findings of this research would be useful for Siloam Hospital in planning various trainings to improve the knowledge and skills of nurses in general and emergency nurses in particular in conducting triage.

\section{Method}

\subsection{Design and Sample}

This quantitative study used a cross sectional design with 25 emergency nurses as the respondents. Those 25 respondents were selected through saturation sampling technique due to the limited number of nurses as the respondent in ER of Siloam Kupang Hospital, Indonesia.

\subsection{Operational Definitions}

ER nurses' knowledge of triage refers to nurses' understanding regarding triage. The level of nurses' knowledge was categorized into good level of knowledge, enough level of knowledge and less level of knowledge about triage. Those levels were measured by a knowledge questionnaire about triage definition, goals, principles, classifications, method, and categorizes.

\subsection{Instruments}

The instruments used in this study were questionnaires and observation sheets using a checklist. The questionnaire used was a standardized questionnaire, adopted from previous research [4] on the factors that affect the accuracy of triage implementation in the ER of Dr. Soedirman Kebumen hospital with a valid r-count test value of 0.572 0.822 where $r$ count $>r$ table $(0.514)$ and a reliable test with Cronbach's Alpha value of 0.935 . The questionnaire consists of 16 items with multiple choices regarding the knowledge of emergency room nurses about triage including the understanding of triage, 1 question (No.1), the principle of implementing triage which is have 4 questions (No.2,3,4,5), 3 questions about triage category (No.6 ,7,8), 3 questions of classification of triage implementation (No.9,10,11), 1 questions regarding method of triage(No.13) and 
3 questions ask about the purpose of $(\mathrm{No} .14,15,16)$. Then the observation sheet consists a checklist of triage implementation that is guided by the Service Operational Standards (SOP) for Triage Implementation in the ER at Siloam Kupang Hospital as many as 22 points.

\subsection{Data Collection Process}

This research has been carried out for 10 days, from September 1, 2021 to September 10, 2021. Initial data collection was carried out after obtaining permission from the Director of Siloam Kupang Hospital, Indonesia. In addition, permits were also obtained from the Chancellor of the University of Citra Bangsa, and the Head of the Emergency room of Siloam Kupang Hospital. The researcher provides information by explaining the purpose of the research to the respondents. After the respondents agreed, they were asked to sign an informed consent. Observations were given by the researcher before giving the triage questionnaire using the observation checklist of triage implementation. Triage questionnaire sheets are not allowed to be taken home. In one shift of service, researchers only observe and give triage questionnaires to nurses who were on duty. For this reason, in one shift the researcher can only observed 1 or 2 respondents. The shift followed by the researcher was uncertain because it was adjusted to the respondent's service schedule.

\subsection{Data Analysis}

All data obtained were processed using statistical applications. Statical Package for the Social Sciences version 15 with chi square test was used to examine the relationship between knowledge and triage implementation in the emergency unit of Siloam Kupang Hospital. The test was carried out after the knowledge category and triage implementation category were carried out. The data of respondents' knowledge regarding triage is processed and categorized according to the standard format and calculation of knowledge level [4]. Meanwhile, the observation data was processed and categorized based on the standard operating procedure (SOP) for triage implementation which is adopted from triage SOP in Siloam Kupang Hospital. 
TABLE 1: Descriptive statistic of respondents' characteristic

\begin{tabular}{l|l|l}
$\begin{array}{l}\text { Characteristics } \\
\text { Age }\end{array}$ & $\mathbf{n}$ & (\%) \\
\hline $\begin{array}{l}25 \text { yo } \\
26-35 \text { yo }\end{array}$ & 11 & 44 \\
Gender & 14 & 56 \\
\hline $\begin{array}{l}\text { Male } \\
\text { Female }\end{array}$ & 11 & 44 \\
\hline $\begin{array}{l}\text { Level of Education } \\
\text { Undergraduate }\end{array}$ & 14 & 56 \\
\hline $\begin{array}{l}\text { Diploma } \\
\text { Working duration }\end{array}$ & 6 & 76 \\
\hline 2 y & 12 & 24 \\
\hline 2 y & 13 & 48 \\
\hline
\end{tabular}

\section{Result}

This study found that from the total of 25 respondents, 14 respondents (56\%) were in the $26-35$ years old category of age and the rest were in $<25$ years old category (44\%). With exactly similar percentage, 14 respondents (56\%) were female and the rest (44\%) were male. Most respondents were in undergraduate level of education, as many as 19 respondents (76\%) and 6 respondents (24\%) were diploma. This research also figured out the respondents working duration, which is divided into two categories, $<2$ years as many as 12 respondents (48\%) and 13 respondents (52\%) have been working for $>2$ years (see table 1).

Source: Primary data, 2021

There are several trainings that had been conduct and followed by the respondent as shown on table 2 , one respondent might be done more than one training, such as Basic Life Support (BLS) had done by nine respondents (36\%). Three (12\%) respondents have followed two kind of training which was Emergency Medical Training (EMT) and Basic Trauma and Cardiac Life Support (BTCLS), seven (28\%) respondents did EMT training, two (8\%) respondents did EMT and EKG, one respondent (4\%) has followed only one training BTCLS and the rest have followed more than one training.

Source: Primary data, 2021

Furthermore, in table 3 below, this study also showed that 11 respondents who had a have good knowledge that did triage implementation according to SOP (44\%). Furthermore 10 respondents who have moderate knowledge regarding triage and did triage implementation without following the SOP (40\%). 
TABLE 2: Distribution of Respondents Based on Training Attended in the Emergency Room Siloam Kupang Hospital $(n=25)$

\begin{tabular}{l|l|l|}
\hline Category & Frekuensi & Percentage (\%) \\
\hline BLS & 9 & 36 \\
\hline EMT & 7 & 28 \\
\hline EMT, EKG, ACLS, PALS & 1 & 4 \\
EMT, BTCLS, ACLS & 1 & 4 \\
EMT. ACLS, BTCLS, EKG & 1 & 4 \\
EMT, BTCLS & 3 & 12 \\
EMT, EKG & 2 & 8 \\
BTCLS & 1 & 4
\end{tabular}

TABLE 3: The Relationship between nurses' knowledge and triage implementation at ER in Siloam Kupang hospital $(n=25)$

Knowledge
Good
Moderate

\begin{tabular}{|l|l|l|}
\hline \multicolumn{2}{|c|}{ Triage Implementation } & p-value \\
\hline Follow SOP & Not follow SOP & \\
\hline $11(44 \%)$ & $2(8 \%)$ & 0.001 \\
\hline $2(8 \%)$ & $10(40 \%)$ & \\
\hline
\end{tabular}

According to the chi square test, nurses' knowledge was related with triage implementation. There is a significant relationship between nurses' knowledge and triage implementation at ER Siloam Kupang Hospital, it was evidenced by statistical results that showed a $p$-value of $0.001(\alpha \leq 0.05)$.

\section{Discussion}

Knowledge of triage implementation is important aspect that the ED nurses must have. It can increase nurses' skill and the effectiveness of triage. Therefore, it necessary to assess emergency nurses' knowledge regarding triage. A research conducted in Bekasi [11] showed a noteworthy relationship between nurses' knowledge and the triage implementation with $\mathrm{P}$-value $=0.030$ and $\mathrm{OR}=0.99$. Meanwhile, this study indicated that 13 respondents (52\%) have good knowledge of triage, 12 respondents (48\%) have moderate knowledge of triage and none of the respondent have poor knowledge. Sahrudi and Anam state that length of working have an influence on the knowledge and skills of nurses in implementing triage because they are often exposed to similar situations and conditions. Moreover, the respondents in this study were also had followed some training related to triage. The data showed that all respondents had follow at least one training and some of them had follow more than one trainings. 
Concerning the implementation of triage, 13 respondents $(52 \%)$ in this study were found could implemented the triage implementation correctly. Whereas, 12 respondents (48\%) were not implementing the triage correctly. A comparative descriptive study [12) reveal that nurses' performance regarding triage can be attributed to the nurses qualification as none of the respondents have a master level of education, most of them were undergraduates level and six (24\%) respondents still have diploma qualification. In addition, Gita and Cemy [13] stated that nurses skill of triage can be affected by age. According to them, age $>30$ years is a mature age in the world of work to perform triage. In this study, 11 respondents (44\%) were < 25 years old and 14 respondents (56\%) were among 24-35 years old. Working experiences can influence nurses' performance in taking appropriate step.

This study showed that nurses' knowledge of triage was significantly related to the implementation of triage with the $p$-value of $0.001(\alpha \leq 0.05)$. The more positive aspects and objects that are known, the more positive attitudes will be shown [14]. According to Martanty and Nofiyanto [8], knowledge starts from knowing and understanding, then during the process, it will be applied (application). Then the knowledge will be analyzed (analysis), next it will be summarized in a logical knowledge which is synthesis. At the final stage, the information will be evaluated in accordance with the norms that apply in society.

Triage that is carried out quickly and precisely is strongly influenced by the knowledge that the nurses have. The results of the study at the ER at Siloam Hospital Kupang, which showed that from 13 nurses who had good knowledge, 11 respondents of them (44\%) carried out triage implementation according to SOP and 2 respondents (8\%) did not apply the triage implementation according to the SOP. While 12 nurses who have moderate knowledge, only 2 respondents (8\%) who did the triage implementation according to SOP and (40\%) were not according to SOP. This finding strengthens the statement from a research conducted by [8], the better the level of knowledge a nurse have, the more skilled will be in implementing triage. By contrast, a negative correlation was found in a cross sectional study in Iran. That study found that there was no significant relationship between knowledge and performance regarding triage. The result of that study showed the moderate level of knowledge respondents give higher performance of triage than the average score. This can be caused due to the knowledge that is considered moderate is actually equivalent to good knowledge in other studies. Moreover, this can also be caused by the fact that the respondent attends the training class with full attention, thus that the skills obtained really increase. 


\section{Limitation}

This research still has several limitations. The first is related to the research location which only covers one hospital, the second is related to the limited number of respondents, the third is related to bias that may arise because the research flow, which is at first informs that the respondent will be observed, so there is a possibility that respondents avoid wrong habits that are still being carried out, the fourth is related to the characteristics of respondents who have attended the training which is greatly varies.

\section{Conclusion}

To conclude, the finding of this study indicate that more than half of the respondents have good knowledge about triage implementation and also more than half of the total respondents who carried out triage according to the SOP. Furthermore, this research also showed that there was a significant correlation between nurses' knowledge level of triage and the triage implementation. However, there were still some nurses who have good knowledge but implement the triage without following the SOP. Therefore, more attention to maintaining, to supervise and to improve nurses' knowledge, skill and obedience in emergency room of Siloam Kupang Hospital is recommended. This can be done through training programs, supervision, and enhancing nurses' motivation. The better the knowledge of nurses, the better the implementation of triage might be done.

\section{Acknowledgment}

We thank to the emergency nurses at Siloam Kupang Hospital who generously helped the process of this study

\section{Funding}

None

\section{Conflict of Interest}

None declared 


\section{References}

[1] Fadli, Sastria A, Usman E. Pelaksanaan triage di instalasi gawat darurat. J Ilm Kesehat Pencerah. 2017;6(1):54-8.

[2] Ainiyah N, Ahsan, Fathoni M. Analisis faktor pelaksanaan triage di instalasi gawat darurat. Jurnal Ners. 2015;10(1):147-57.

[3] Amri A, Manjas M, Hardisman H. Analisis implementasi triage, ketepatan diagnosa awal dengan lama waktu rawatan pasien di RSUD Prof. DR. MA Hanafiah SM Batusangkar. Jurnal Kesehatan Andalas. 2019;8(3):484.

[4] Irawati W. Faktor faktor yang mempengaruhi ketepatan pelaksanaan triage di instalasi gawat darurat RSUD Dr. SOEDIRMAN KEBUMEN. Sekolah Tinggi IImu Kesehatan Muhammadiyah Gombong; 2017.

[5] Wahyuni ED. Hubungan pengetahuan perawat tentang pemberian label triase dengan tindakan perawat berdasarkan label triase di igd rumah. Jurnal Keperawatan. 2018:33-7.

[6] Roihatul Z, Ahmad BH, Elok K. Pengetahuan standart labeling triage dengan tindakan kegawatan berdasarkan standart labeling triage. Jurnal Keperawatan dan Kesehatan Masyarakat STIKES Cendekia Utama Kudus. 2020;9(3):252-9.

[7] Khairina I, Malini H, Huriani E. Faktor-faktor yang berhubungan dengan pengambilan keputusan perawat dalam ketepatan triase di kota padang. Indonesia Journal Health Science. 2018;2(1):1.

[8] Martanti R, Nofiyanto M, Prasojo RAJ, Jendral S, Yani A. Hubungan tingkat pengetahuan dengan keterampilan petugas dalam pelaksanaan triage di instalasi gawat darurat rsud wates. 2015;4(2):69-76.

[9] Ramadhan MF, Wiryansyah OA. Hubungan tingkat pengetahuan perawat tentang response time dalam menentukan triase diruang igd. Jurnal Kesehatan dan Pembang. 2020;10(19):56-62.

[10] Khairina I, Malini H, Huriani E. Pengetahuan dan keterampilan perawat dalam pengambilan keputusan klinis triase. 2020;16(1):1-5.

[11] Sahrudi AA. Pengetahuan dan sikap perawat terhadap tindakan triase di instalasi gawat darurat. NERS Jurnal Keperawatan. 2021;17(1):14-20.

[12] Mustafa SA, Adam S. Triage. 2019;10(3):50-63.

[13] Gita NA. Hubungan antara pengetahuan dan sikap perawat tentang triage. 2013:187. 
[14] Nurbiantoro DA, Septimar ZM, Winarni LM. Hubungan pengetahuan dengan keterampilan perawat dalam pelaksanaan triase di rsud kota tangerang. Journal of Health Sains. 2020;1(6):414-26. 